\title{
Host range of Lepidelphax pistiae (Hemiptera: Delphacidae) and its potential impact on Pistia stratiotes L. (Araceae)
}

\author{
Ashley B. C. Goode (D) a , Carey R. Minteer ${ }^{b}$, Jeremiah R. Foleyc, Philip W. Tipping ${ }^{a}$, \\ Ryann J. Valmonte ${ }^{a}$, Brittany K. Knowles ${ }^{a}$ and Lyn A. Gettys ${ }^{d}$ \\ aUSDA-ARS Invasive Plant Research Laboratory (IPRL), Ft. Lauderdale, FL, USA; ${ }^{b}$ University of Florida Indian \\ River Research and Education Center, Fort Pierce, FL, USA; 'Department of Entomology, Virginia Polytechnic \\ Institute and State University, Blacksburg, VA, USA; dUniversity of Florida Fort Lauderdale Research and \\ Education Center, Ft. Lauderdale, FL, USA
}

\begin{abstract}
Pistia stratiotes L. (Araceae) is a floating aquatic plant that has become invasive in Florida. It is primarily controlled with herbicides, but two biocontrol agents have previously been released to assist in management of this species. A new potential biocontrol agent from Argentina, Lepidelphax pistiae Remes Lenicov (Hemiptera: Delphacidae), has been evaluated comprehensively for specificity after initial host range studies done in its native range indicated that it is likely specific to $P$. stratiotes. Host range studies indicated that this insect is specific to $P$. stratiotes, with no survival or reproduction occurring on any of the 42 other plant species tested. Impact studies indicated that this insect can significantly damage $P$. stratiotes at medium and high population densities, which were comparable to those seen in its native range. Lepidelphax pistiae is sufficiently specific enough to warrant release and has a high probability of aiding management of $P$. stratiotes populations in Florida.
\end{abstract}

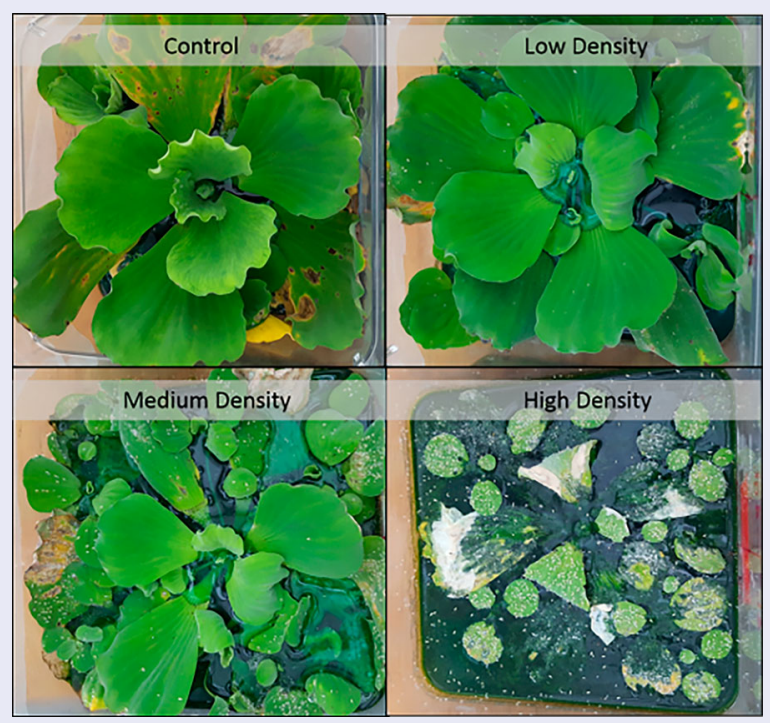

\section{ARTICLE HISTORY}

Received 1 October 2018

Returned 20 February 2019

Accepted 23 February 2019

\section{KEYWORDS}

Waterlettuce; aquatic plant; biological control;

Lepidelphax pistiae

CONTACT Ashley B. C. Goode ashley.goode@ars.usda.gov E USDA-ARS Invasive Plant Research Laboratory (IPRL), 3225 College Ave., Ft. Lauderdale, FL, 33314, USA 
Waterlettuce (Pistia stratiotes L. [Araceae]) is an invasive aquatic plant that has been introduced to many countries (Holm, Plucknett, Pancho, \& Herberger, 1977; Neuenschwander, Julien, Center, \& Hill, 2009). It threatens native habitats because it grows quickly, alters water chemistry, blocks sunlight (which affects submerged vegetation, fish, and aquatic invertebrates), impedes navigation, and clogs flood control structures (Neuenschwander et al., 2009). In Florida, it also harbours mosquito larvae (Lounibos \& Escher, 1985; Neuenschwander et al., 2009). It is on the Florida Prohibited Aquatic Plants List (Florida Administrative Code, 2008) and is a Category I Plant on the Florida Exotic Pest Plant Council's (FLEPPC) List of Invasive Plant Species (FLEPPC, 2017). To attempt to control this species, the biocontrol agents Neohydronomus affinis Hustache (Coleoptera: Curculionidae; Dray et al., 1990; Dray \& Center, 1992) and Spodoptera pectinicornis Hampson (Lepidoptera: Noctuidae; Dray, Center, \& Wheeler, 2001; Grodowitz, Johnson, \& Nelson, 1992) were released in Florida in 1987 and 1990, respectively. While N. affinis is confirmed as established, S. pectinicornis did not establish (Dray et al., 2001). Neohydronomus affinis has been credited in controlling P. stratiotes in Australia (Harley, Kassulke, Sands, \& Day, 1990) and parts of Africa (Ajuonu \& Neuenschwander, 2003; Chikwenhere, 1994; Hill \& Moore, 2012). Lab experiments suggest that a single pair of weevils per plant can effectively control P. stratiotes (Diop, Coetzee, \& Hill, 2010). Past evaluations in Florida indicated that it had established populations (Dray \& Center, 1992); however, no recent evaluations of $N$. affinis have been conducted and so its population and impact is currently unknown and P. stratiotes is still considered a major ecological issue in the state (FLEPPC, 2017).

Herbicide application is the preferred management strategy for keeping floating aquatic vegetation (mainly P. stratiotes and Pontederia [Eichhornia] crassipes [Martius] Solms. [Pontederiaceae]) at maintenance levels in Florida. Because this is a management strategy, herbicide application must be done regularly and in perpetuity to maintain population control, costing millions of dollars annually (Netherland, Getsinger, \& Stubbs, 2005). In order to improve the suppression of this plant, a new potential biocontrol agent, Lepidelphax pistiae de Remes Lenicov (Hemiptera: Delphacidae) was collected from Argentina for evaluation.

Lepidelphax pistiae was described from the Paraná/Uruguay basin in Argentina and is the only species within the Lepidelphax genus (de Remes Lenicov \& Walsh, 2013). It has been observed feeding and reproducing only on $P$. stratiotes both in the field and the laboratory (Cabrera Walsh, Maestro, Sosa, \& Tipping, 2014; de Remes Lenicov \& Walsh, 2013; de Remes Lenicov, Defea, Rusconi, \& Cabrera Walsh, 2017). Lepidelphax pistiae by itself can significantly impact growth of $P$. stratiotes, reducing final biomass by approximately one third and resulting in $\sim 20 \%$ fewer rosettes compared to controls (Cabrera Walsh \& Maestro, 2014). Other studies on this species show that L. pistiae, together with Neohydronomous affinis, reduce $P$. stratiotes biomass and coverage in field settings (Cabrera Walsh \& Maestro, 2016).

Previously, host range testing of L. pistiae was conducted at Fundación para el Estudio de Especies Invasivas (FUEDEI) in Hurlingham, Buenos Aires, Argentina and at the USDA-ARS Invasive Plant Research Laboratory (IPRL) in Ft. Lauderdale, FL, USA. This testing involved no-choice specificity tests on 25 species of Araceae and four additional wetland plant species with $100 \%$ adult mortality and no progeny produced on any plant other than P. stratiotes (Cabrera Walsh et al., 2014). Herein, L. pistiae was 
Table 1. List of plant species used in the Lepidelphax pistiae host range test with mean survival \pm SE of $P_{1}$ L. pistiae and mean number $\pm \mathrm{SE}$ of $F_{1}$ progeny recovered from each.

\begin{tabular}{|c|c|c|c|c|c|c|}
\hline Order & Family & Scientific Name & Common name & $\begin{array}{c}\text { NA } \\
\text { Status } \\
\end{array}$ & $\begin{array}{c}\% P_{1} \\
\text { Survival } \\
\text { Mean } \pm \text { SE }\end{array}$ & $\begin{array}{c}\# F_{1} \\
\text { Progeny } \\
\text { Mean } \pm S E \\
\end{array}$ \\
\hline Acorales & Acoraceae & Acorus calamus L. & $\begin{array}{l}\text { sweet flag, } \\
\text { calamus }\end{array}$ & Exotic & 0 & 0 \\
\hline \multirow[t]{21}{*}{ Alismatales } & Alismataceae & Echinodorus bleheri Rataj & $\begin{array}{l}\text { Amazon sword } \\
\text { plant }\end{array}$ & Exotic & 0 & 0 \\
\hline & & $\begin{array}{l}\text { Echinodorus cordifolius } \\
\text { Engelmann }\end{array}$ & spade-leaf sword & Native & 0 & 0 \\
\hline & & $\begin{array}{l}\text { Hydrocleys nymphoides } \\
\text { Humb. \& Bonpl. ex Willd. }\end{array}$ & water poppy & Exotic & 0 & 0 \\
\hline & & Sagittaria japonica L. & $\begin{array}{l}\text { double-flowing } \\
\text { arrowhead }\end{array}$ & Exotic & 0 & 0 \\
\hline & & Sagittaria lancifolia L. & duck potato & Native & 0 & 0 \\
\hline & & $\begin{array}{l}\text { Sagittaria montevidensis } \\
\text { Cham. \& Schltdl. }\end{array}$ & giant arrowhead & Native & 0 & 0 \\
\hline & & Sagittaria subulata L. & $\begin{array}{l}\text { awl-leaf } \\
\text { arrowhead }\end{array}$ & Native & 0 & 0 \\
\hline & Araceae & Alocasia cucullata L. & Chinese Taro & Exotic & 0 & 0 \\
\hline & & $\begin{array}{l}\text { Anthurium andraeanum } \\
\text { Linden ex André }\end{array}$ & anthurium & Exotic & 0 & 0 \\
\hline & & $\begin{array}{l}\text { Anthurium scandens } \\
\text { (Aubl.) Engl. }\end{array}$ & pearl laceleaf & Exotic & 0 & 0 \\
\hline & & Arisaema triphyllum L. & jack-in-the-pulpit & Native & 0 & 0 \\
\hline & & $\begin{array}{l}\text { Caladium bicolor (Aiton) } \\
\text { Vent. }\end{array}$ & wild cocoyam & Exotic & 0 & 0 \\
\hline & & $\begin{array}{l}\text { Cryptocoryne wendtii de } \\
\text { Wit }\end{array}$ & & Exotic & 0 & 0 \\
\hline & & Orontium aquaticum L. & $\begin{array}{l}\text { golden-club, } \\
\text { floating arum }\end{array}$ & Native & 0 & 0 \\
\hline & & Peltandra virginica $\mathrm{L}$. & $\begin{array}{l}\text { green arrow arum, } \\
\text { tuckahoe }\end{array}$ & Native & 0 & 0 \\
\hline & & Pistia stratiotes L. & waterlettuce & Exotic & $63 \pm 4.7$ & $84.8 \pm 9.3$ \\
\hline & & Symplocarpus foetidus L. & $\begin{array}{l}\text { eastern skunk } \\
\text { cabbage }\end{array}$ & Native & 0 & 0 \\
\hline & Butomaceae & Butomus umbellatus L. & flowering rush & Exotic & 0 & 0 \\
\hline & Juncaginaceae & Triglochin maritimum L. & seaside arrowgrass & Exotic & 0 & 0 \\
\hline & Lemnaceae & Lemna minor L. & $\begin{array}{l}\text { common (lesser) } \\
\text { duckweed }\end{array}$ & Native & 0 & 0 \\
\hline & Tofieldiaceae & $\begin{array}{l}\text { Triantha racemosa (Walter) } \\
\text { Small }\end{array}$ & $\begin{array}{l}\text { coastal false } \\
\text { asphodel }\end{array}$ & Native & 0 & 0 \\
\hline Asparagales & Amaryllidaceae & $\begin{array}{l}\text { Zephyranthes minuta } \\
\text { (grandiflora) (Kunth) } \\
\text { D.Dietr. }\end{array}$ & pink rain lily & Exotic & 0 & 0 \\
\hline \multirow[t]{2}{*}{ Commelinales } & Commelinaceae & $\begin{array}{l}\text { Tradescantia pallida (Rose) } \\
\text { D.R. Hunt }\end{array}$ & purple queen & Native & 0 & 0 \\
\hline & Haemodoraceae & $\begin{array}{l}\text { Lachnanthes caroliniana } \\
\text { (Lem.) }\end{array}$ & redroot & Native & 0 & 0 \\
\hline Lamiales & Plantaginaceae & $\begin{array}{l}\text { Plantago major } \\
\quad \text { (atropurpurea) L. }\end{array}$ & $\begin{array}{l}\text { purple leaf } \\
\text { plantain }\end{array}$ & Exotic & 0 & 0 \\
\hline Malvales & Malvaceae & $\begin{array}{l}\text { Abelmoschus esculentus (L.) } \\
\text { Moench }\end{array}$ & okra & Crop & 0 & 0 \\
\hline \multirow[t]{2}{*}{ Nymphaeales } & Nymphaeaceae & $\begin{array}{l}\text { Nymphaea mexicana } \\
\text { Zuccarini }\end{array}$ & yellow waterlily & Native & 0 & 0 \\
\hline & Nymphaeaceae & Nymphaea odorata Ait. & $\begin{array}{l}\text { American white } \\
\text { waterlily }\end{array}$ & Native & 0 & 0 \\
\hline \multirow[t]{5}{*}{ Poales } & Cyperaceae & Cladium jamaicense L. & saw-grass & Native & 0 & 0 \\
\hline & Juncaceae & Juncus effucus L. & common rush & Native & 0 & 0 \\
\hline & Poaceae & Oryza sativa $\mathrm{L}$. & Asian rice & Crop & 0 & 0 \\
\hline & Poaceae & Saccharum officinarum L. & sugarcane & Crop & 0 & 0 \\
\hline & Poaceae & & & Native & 0 & 0 \\
\hline
\end{tabular}


Table 1. Continued.

\begin{tabular}{|c|c|c|c|c|c|c|}
\hline Order & Family & Scientific Name & Common name & $\begin{array}{c}\text { NA } \\
\text { Status }\end{array}$ & $\begin{array}{c}\% P_{1} \\
\text { Survival } \\
\text { Mean } \pm \text { SE }\end{array}$ & $\begin{array}{c}\# F_{1} \\
\text { Progeny } \\
\text { Mean } \pm \text { SE }\end{array}$ \\
\hline & & $\begin{array}{l}\text { Spartina patens (Aiton) } \\
\text { Muhl. }\end{array}$ & $\begin{array}{l}\text { saltmeadow } \\
\text { cordgrass }\end{array}$ & & & \\
\hline & Poaceae & $\begin{array}{l}\text { Stenotaphrum secundatum } \\
\text { (Walter) Kuntze }\end{array}$ & St. Augustine grass & Native & 0 & 0 \\
\hline & Poaceae & Zea mays $\mathrm{L}$. & corn & Crop & 0 & 0 \\
\hline \multirow[t]{2}{*}{ Zingiberales } & Cannaceae & $\begin{array}{l}\text { Canna americanallis } \\
\text { variegata }\end{array}$ & bengal tiger canna & Exotic & 0 & 0 \\
\hline & Costaceae & Costus woodsonii Maas. & red button ginger & Exotic & 0 & 0 \\
\hline
\end{tabular}

tested on an additional 37 plant species including common landscaping plants and economically important crops, along with additional members of the Araceae family, both native and exotic to Florida. The effects of $L$. pistiae were also tested to determine the damage this species could inflict directly on P. stratiotes.

\section{Methods and materials}

\section{Host range and oviposition testing}

No-choice specificity tests were conducted on non-target plants (Table 1 ) in a quarantine greenhouse at IPRL under natural light conditions, $25-27^{\circ} \mathrm{C}$, and $70-85 \% \mathrm{RH}$. Test plants were selected based on their relatedness to $P$. stratiotes, use of similar habitats, and economic importance. Testing was done using whole plants because L. pistiae feeds on the plant's fluids. Damage from this insect is seen primarily as 'hopper burn' (chlorosis) on leaves and mean growth rate reduction (de Remes Lenicov \& Walsh, 2013). Feeding from an individual insect is difficult to detect, so $P_{1}$ survival and $F_{1}$ nymph emergence were used as a sign of host plant suitability. Caging appropriate for each plant type and size was used and included sleeved cages and $40 \mathrm{~L}$ aquaria or $5 \mathrm{~L}$ plastic jars with screened lids.

A randomised, complete block design with five replications of each test plant species was used throughout and each trial contained three to five plant species at a time, including a $P$. stratiotes control. Each test plant was enclosed separately and five (3 $\$$ / 2 ऽ) 1-2 week old $L$. pistiae adults were placed on each plant for seven days; they were then removed and the $P_{1}$ mortality was recorded. Test plants and $P$. stratiotes control plants were then monitored for appearance of $F_{1}$ adults. Monitoring was discontinued after $F_{1}$ adults were found on $P$. stratiotes control plants.

Insects were also tested for longevity without access to $P$. stratiotes or water to simulate what would occur if all of their host plant died off or they were accidentally transported away from their host plant. A randomised design with ten replicates of each treatment was used and the experiment was repeated three times with equal numbers of male and female L. pistiae. Each replicate consisted of a single L. pistiae placed in a $500 \mathrm{~mL}$ plastic container closed with a friction fitting, screened lid that contained either one P. stratiotes rosette in fertilised water (water soluble fertiliser [Peters Professional 24-8-16 Fertilizer, Everris, Geldermalsen, Netherlands] at a rate of $1 \mathrm{~g} / 5 \mathrm{~L}$ deionised water), one filter paper sheet moistened with DI water (water only treatment), or nothing (control). The filter paper was remoistened as necessary during the experiment and treatments were 
monitored twice daily for insect mortality until $100 \%$ mortality occurred in the water and control treatments.

\section{Impact testing}

Two experiments were conducted to evaluate the impact of L. pistiae on P. stratiotes: 1) a two-treatment randomised block design with five blocks and, 2) a four-treatment randomised block design with six blocks. For the two-treatment experiment (repeated four times between February 2017 and March 2018), a low density insect treatment $(2$ o / 1 đ L. pistiae) was compared to a no-insect control treatment. For the four-treatment experiment (conducted May through June 2018), three insect densities of L. pistiae (low - 2 \% / 1

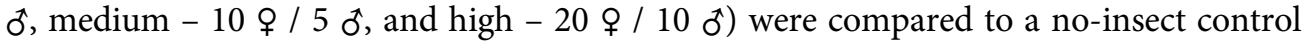
treatment. Densities were chosen based on previous experiments done in Argentina, where $30 \mathrm{~L}$. pistiae were able to negatively impact caged areas of P. stratiotes (Cabrera Walsh \& Maestro, 2014). Cabrera Walsh and Maestro (2014) also noted that L. pistiae is highly mobile in the field, so the medium and low density treatments in this current experiment were meant to mimic other observed field densities.

For each sample, one $P$. stratiotes rosette was placed in an $11 \mathrm{~L}$ plastic tub with a screen lid. Initial fresh weight biomass of each $P$. stratiotes was recorded, as well as the number of leaves within each tub.

Plants were fertilised with the same water-soluble fertiliser and rate used as before, and Aquashade (Arch Chemicals, Inc., Germantown, Wisconsin) was added at the label rate to reduce algal growth. For the insect treatments, 1-2 week old brachypterous adult L. pistiae were placed in each insect treatment tub for 1 week and then removed and mortality recorded. Any $F_{1}$ nymphs that emerged were permitted to develop into adults, which were counted and removed over the course of 1-2 weeks. Final fresh weight biomass of each $P$. stratiotes was recorded, as well as the final number of rosettes and leaves within each tub.

\section{Statistical analysis}

Analyses were performed using R (version 3.3.2; R Core Team, 2016). For the two-treatment impact experiments, treatments and blocks were compared using ANOVAs to determine differences in initial fresh weight and number of leaves and two sample t-tests were used to compare changes in fresh weight, number of leaves, and number of rosettes. For the four-treatment impact experiment, treatments and blocks were compared using ANOVA. Data were then evaluated post-hoc using Tukey's tests to determine differences among treatments. A significance level of $\alpha<0.05$ was used for all statistical tests.

\section{Results and discussion}

\section{Host range and oviposition}

Adult L. pistiae did not survive on, nor did any nymphs emerge from, any plants except for $P$. stratiotes, where up to 204 nymphs emerged from each plant (Mean ( \pm SE) number of nymphs $=84.8 \pm 9.26$; average $P_{1}$ survival $=0.63 \pm 0.047$ ) (Table 1$)$. Mean survival of adults was $1.38 \pm 0.10$ days in the water only treatment and $0.63 \pm 0.04$ days in the 
control treatment. Average survival of $L$. pistiae under the same ambient conditions in the $P$. stratiotes treatment was $70 \pm 8.5 \%$ over three days, similar to what was seen in the host range no-choice tests. The no-choice experiments show that in the event that this insect is separated from its host plant, the adults are not able to survive more than a few days without feeding. The specificity of this insect and its inability to survive off of its host plant for any significant period indicate that it would be a safe biological control agent for P. stratiotes.

\section{Impact}

There was no significant difference in initial fresh weight or initial number of leaves between treatments or blocks in the two-treatment impact experiment. At low density

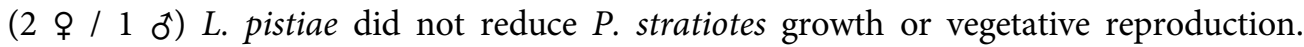
There was a change in fresh weight $(d f=3, F=26.65, p<0.001)$ and a difference in total $F_{1} L$. pistiae $(d f=3, F=7.483, p=0.00167)$ among treatments in the four-treatment experiment. Further, Tukey's tests indicated that the control and low density treatments had greater increases in fresh weight compared to the medium and high density treatments $(p<0.001$, Figure 1). The impact experiments found lower insect densities did

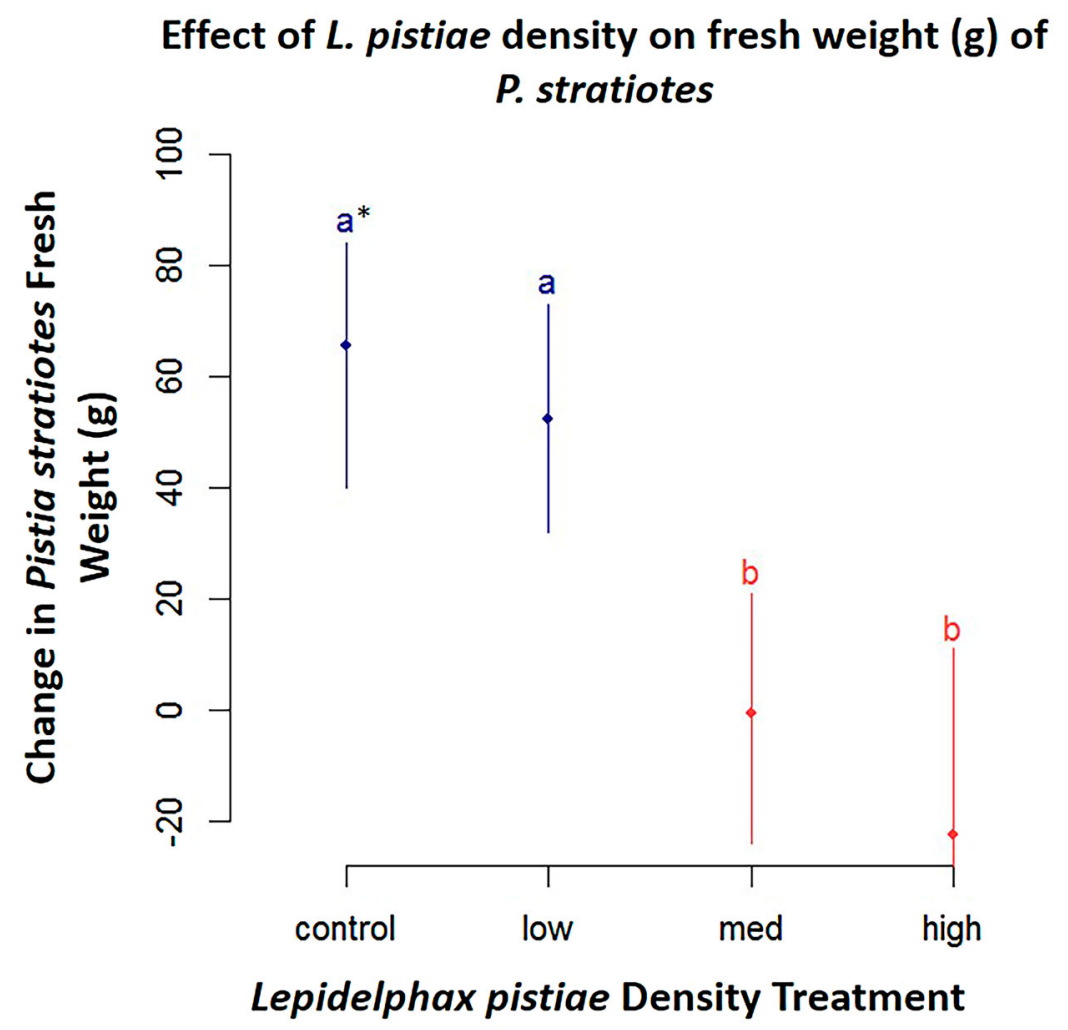

Figure 1. Effect of $L$. pistiae density on fresh weight $(\mathrm{g})$ of $P$. stratiotes. Mean ( $\pm \mathrm{SE}$ ) change in the biomass of $P$. stratiotes when exposed to a range of densities of $L$. pistiae. *Letters indicate significant differences determined by Tukey's test at $p<0.05$. 


\section{Effect of $L$. pistiae density on number of $F_{1}$ L. pistiae adults}
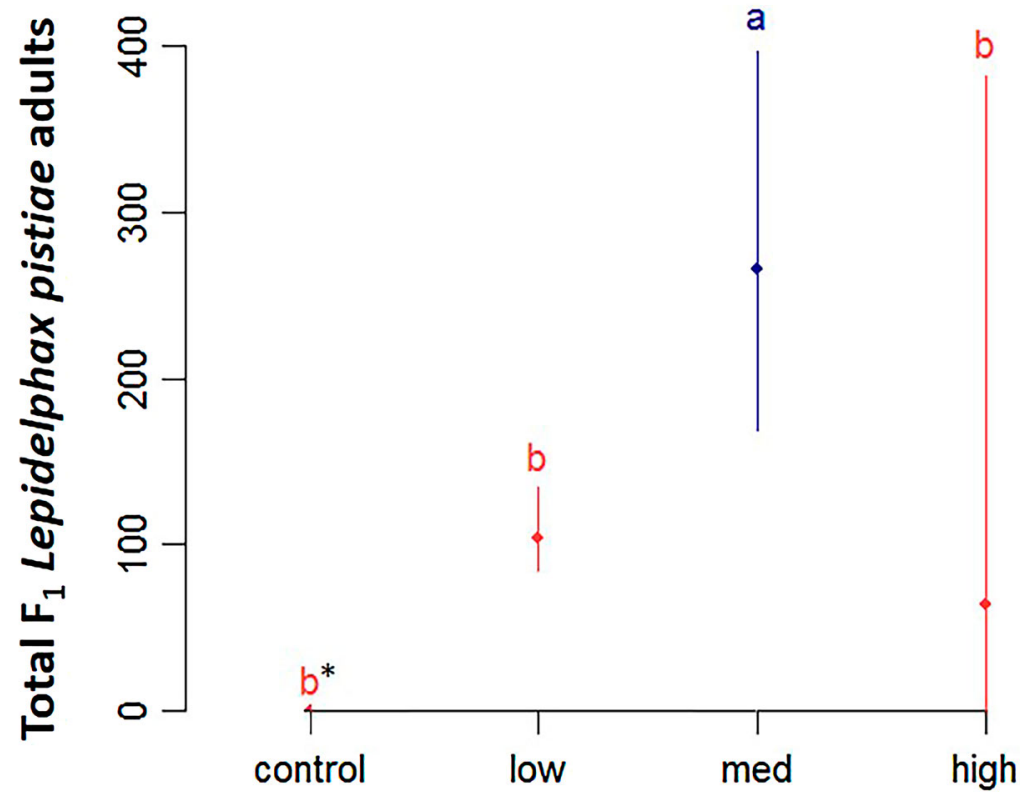

\section{Lepidelphax pistiae Density Treatment}

Figure 2. Effect of $L$. pistiae density on the number of $F_{1} L$. pistiae adults. Mean ( $\pm \mathrm{SE}$ ) number of $F_{1}$ adults produced under different initial densities of $L$. pistiae. The high density treatment only had one replication with live plant material at the end of the experiment. *Letters indicate significant differences determined by Tukey's test at $p<0.05$.

not affect the growth rate of $P$. stratiotes while moderate to higher densities did. The high density treatment resulted in the complete destruction of the experimental plant population, thereby causing the insects to starve and the final total $F_{1}$ count to be zero for most of the samples. This explains why the medium density treatment had significantly more total $F_{1} L$. pistiae than either of the other insect treatments or the control $(p<$ 0.05 , Figure 2).

In a previous lab study, L. pistiae reached similarly high densities to those in this study (Cabrera Walsh et al., 2014). In field studies in the native range of L. pistiae, caged plots containing $P$. stratiotes that were exposed to $30 \mathrm{~L}$. pistiae adults (comparable to the high density impact treatment in this study) produced lower biomass and plants with smaller diameters than those in control enclosures (Cabrera Walsh \& Maestro, 2014). Lepidelphax pistiae also produced high population densities and dispersed across a $7,000 \mathrm{~m}^{2}$ lake within 40 days of release (Cabrera Walsh \& Maestro, 2016). In this study, L. pistiae exposures at medium density resulted in a $\sim 36 \%$ increase in biomass, compared to $a>$ $200 \%$ increase on average in the control treatment. These results suggest that, if released, 
this insect may be able to reach useful densities in the field and cause significant damage to P. stratiotes.

Lepidelphax pistiae has been shown to be highly specific to $P$. stratiotes and can be damaging at medium and higher densities, indicating that it would be a suitable biological control agent for this species. However, the question of whether P. stratiotes is native to Florida must be considered and requires further research (Evans, 2013).

\section{Disclosure statement}

No potential conflict of interest was reported by the authors.

\section{ORCID}

Ashley B. C. Goode (D) http://orcid.org/0000-0001-6515-3954

\section{References}

Ajuonu, O., \& Neuenschwander, P. (2003). Release, establishment, spread and impact of the weevil Neohydronomus affinis (Coleoptera: Curculionidae) on water lettuce (Pistia stratiotes) in Benin, West Africa. African Entomology, 11(2), 205-211.

Cabrera Walsh, G., \& Maestro, M. (2014). Evaluation of intraguild interactions between two species of insect herbivores on Pistia stratiotes. Biological Control, 76, 74-78.

Cabrera Walsh, G., \& Maestro, M. (2016). Impact of introduced native herbivores on a Pistia stratiotes infestation close to the Paraná Delta in Argentina. Biocontrol Science and Technology, 26 (1), 35-46.

Cabrera Walsh, G., Maestro, M., Sosa, A., \& Tipping, P. W. (2014). Specificity of Lepidelphax pistiae (Hemiptera: Delphacidae) to Pistia stratiotes (Araceae). Biocontrol Science and Technology, 24(4), $485-488$.

Chikwenhere, G. P. (1994). Biological control of water lettuce in various impoundments of Zimbabwe. Journal of Aquatic Plant Management, 32, 27-29.

de Remes Lenicov, A. M. M., Defea, B., Rusconi, J., \& Cabrera Walsh, G. (2017). Studies on the immature stages of the planthopper Lepidelphax pistiae (Hemiptera: Delphacidae), a potential biocontrol agent for the aquatic weed Pistia stratiotes (Araceae) from Argentina. Austral Entomology, 56(4), 384-391.

de Remes Lenicov, A. M. M., \& Walsh, G. C. (2013). A new genus and species of Delphacini (Hemiptera: Fulgoromorpha: Delphacidae) associated with hydrophytic plants in Argentina. Florida Entomologist, 96(4), 1350-1358.

Diop, O., Coetzee, J. A., \& Hill, M. P. (2010). Impact of different densities of Neohydronomus affinis (Coleoptera: Curculionidae) on Pistia stratiotes (Araceae) under laboratory conditions. African Journal of Aquatic Science, 35(3), 267-271.

Dray, F. A., \& Center, T. D. (1992). Biological control of Pistia stratiotes L. (waterlettuce) using Neohydronomus affinis Hustache (Coleoptera: Curculionidae) (Miscellaneous Paper A-92-1). Waterways Experiment Station Vicksburg, MS: U.S. Army Corps of Engineers.

Dray, F. A., Center, T. D., Habeck, D. H., Thompson, C. R., Cofrancesco, A. F., \& Balciunas, J. K. (1990). Release and establishment in the Southeastern United States of Neohydronomus affinis (Coleoptera: Curculionidae), an herbivore of waterlettuce. Environmental Entomology, 19, 799-802.

Dray, F. A., Center, T. D., \& Wheeler, G. S. (2001). Lessons from unsuccessful attempts to establish Spodoptera pectinicornis (Lepidoptera: Noctuidae), a biological control agent of waterlettuce. Biocontrol Science and Technology, 11, 301-316. 
Evans, J. M. (2013). Pistia stratiotes L. in the Florida Peninsula: Biogeographic evidence and conservation implications of native tenure for an 'invasive' aquatic plant. Conservation and Society, 11, 233-246.

Florida Administrative Code. (2008). 5B-64.011 prohibited aquatic plants.

Florida Exotic Pest Plant Council [FLEPPC]. (2017). List of invasive plant species. Florida exotic pest plant council.

Grodowitz, M. J., Johnson, W., \& Nelson, L. D. (1992). Status of biological control of water lettuce in Louisiana and Texas using insects (Miscellaneous Paper A-92-3). Waterways Experiment Station Vicksburg, MS: U.S. Army Corps of Engineers.

Harley, K. L. S., Kassulke, R. C., Sands, D. P. A., \& Day, M. D. (1990). Biological control of water lettuce, Pistia stratiotes [Araceae] by Neohydronomus affinis [Coleoptera: Curculionidae]. Entomophaga, 35(3), 363-374.

Hill, M. P., \& Moore, G. R. (2012). A quantitative post-release evaluation of biological control of water lettuce, Pistia stratiotes L. (Araceae) by the weevil Neohydronomus affinis Hustache (Coleoptera: Curculionidae) at Cape Recife Nature Reserve, Eastern Cape Province, South Africa. African Entomology, 20(2), 380-385.

Holm, L. G., Plucknett, D. L., Pancho, J. V., \& Herberger, J. P. (1977). The world's worst weeds: Distribution and biology. Honolulu: University Press of Hawaii.

Lounibos, L. P., \& Escher, R. L. (1985). Mosquitoes associated with water lettuce (Pistia stratiotes) in southeastern Florida. Florida Entomologist, 68(1), 169-178.

Netherland, M. D., Getsinger, K. D., \& Stubbs, D. R. (2005). Aquatic plant management: Invasive species and chemical control. Outlooks on Pest Management, 16(3), 100-104.

Neuenschwander, P., Julien, M. H., Center, T. D., \& Hill, M. P. (2009). Pistia stratiotes L. (Araceae). In R. Muniappan, G. V. P. Reddy, \& A. Raman (Eds.), Biological control of tropical weeds using arthropods (pp. 332-352). New York: Cambridge University Press.

$\mathrm{R}$ Core Team. (2016). R: A language and environment for statistical computing. Vienna: $\mathrm{R}$ Foundation for Statistical Computing. 